

\title{
Política da imagem, subjetivação e cenas de dissenso
} Image policy, subjectivation and argument scenes

\author{
Ângela Marques*
}

Resumo: Este artigo pretende abordar, à luz da reflexão de Jacques Rancière, como a política da imagem se revela na produção criativa de cenas dissensuais nas quais o sujeito político emerge, aparece e constitui-se através de um processo de subjetivação. A potência política e criativa que as imagens apresentam conecta-se aos gestos de sobrevivência: operações e agenciamentos que possibilitam e que permitem resistir a capturas, silêncios e aos excessos de discursos construídos midiaticamente, pelas instituições sociais e pelo Estado.

Palavras-chave: Política da imagem. Subjetivação. Cenas de dissenso. Rosto. Jacques Rancière.

\begin{abstract}
This paper is aimed at discussing, with focus on Jacques Rancière, how an image policy can be noticed in the creative production of scenes of dissent from which the political agent emerge, appears and constitute himself in a process of subjectivation. The political and critical power of the image is linked to survival acts: operations and attempts that enable to resist to captures, silences and excesses comitted by the media discourses, by the social institutions and by the State.
\end{abstract}

Keywords: Image policy. Subjectivation. Argument scenes. Face. Jacques Rancière.

* Professora do Departamento de Comunicação Social e do Programa de Pós-Graduação em Comunicação Social da Universidade Federal de Minas Gerais (UFMG). Mestre e Doutora em Comunicação pela mesma instituição. E-mail: angelasalgueiro@gmail.com 


\section{Introdução}

Quais elementos conferem uma dimensão política às imagens? Essa questão está presente em reflexões apresentadas por Jacques Rancière (2008 a e b, 2009, 2010 a e b, 2012) acerca da potência que as imagens possuem não apenas de mostrar o visível, mas de fornecerem pistas acerca do dispositivo por meio do qual o visível é apreendido. Segundo Rancière (2010a), há hoje uma tentativa de se evidenciar que imagens e obras artísticas são políticas, sobretudo devido às mensagens que desejariam transmitir, enfatizando estigmas de dominação, questionando estereótipos, convocando os espectadores a assumirem uma postura crítica, muitas vezes de indignação e revolta. Ele afirma que a política não pode ser identificada como uma instrução fornecida pelas imagens (e obras artísticas) para a indignação, o assombro, a constestação da injustiça, o compadecimento ou mesmo o horror.

Um dos problemas em associar política e imagem (e mesmo política e arte), segundo ele, está na crença em uma continuidade imediata entre os conteúdos de determinada imagem e as formas do pensamento sensível que se estabelecem na recepção. Como se houvesse um roteiro previamente estabelecido de leitura, interpretação e posicionamento diante das imagens. Rancière afirma que a política das imagens não está em seus conteúdos e nem se concretiza como uma instrução para olhar para o mundo e transformá-lo através da tomada de consciência de formas opressoras. A imagem não é um guia para a ação política e nem um instrumento de conscientização massiva. É por isso mesmo, que Rancière salienta que (2010a, p.100) "as imagens da arte não fornecem armas de combate. Contribuem para desenhar configurações novas do visível, do dizível e do pensável e, por isso mesmo, uma paisagem nova do possível." Ele afirma não existem fórmulas que prescrevem como a imagem deve orientar os sujeitos em suas ações e interpretações. "Quando um artista está preocupado em "passar uma mensagem" política não faz outra coisa senão infantilizar o espectador" (HUSSAK, 2012, p.102). 
Ao questionar o pressuposto dessa continuidade existente entre a produção das imagens e a percepção sensível em uma situação de recepção que envolve os pensamentos, sentimentos e ações dos espectadores, Rancière (2010a) afirma que a política das imagens só pode ser percebida por meio da eliminação do continuum existente entre o intuito do artista e a interpretação do espectador. $\mathrm{O}$ artista, segundo Rancière, não tem controle sobre os efeitos e apropriações de sua arte, ele não pode afirmar, com certeza, que ela é política, afinal isso diz de uma interpretação livre do espectador. Sendo assim, é preciso que haja um intervalo entre a arte e o modo como o sujeito entra em contato com ela, um livre jogo no qual a arte não solicita nada do espectador e o espectador não deve produzir nenhuma ação sob os pretensos ditames da arte. É esse "livre jogo" que está na base do conceito de "regime estético" da arte proposto por esse autor.

Ao entendimento da imagem como cópia (mímese) ou reprodução/ representação do real (regime representativo), Rancière opõe um modo de compreensão da imagem que escapa ao pressuposto de que há uma relação necessária de causa-efeito entre o que a obra mostra e a recepção do espectador, ou, ainda, que a intenção do artista vai provocar uma mudança repentina e profunda nos quadros de sentido que orientam a percepção de mundo do espectador. "Nesta perspectiva, a politicidade da arte, tal como Rancière pensa, está na suspensão de toda relação determinável entre a intenção da produção e efeito na recepção" (HUSSAK, 2012, p.103). Por isso, o lugar da política na arte, segundo Rancière, não é aquele que pretende usar a representação para corrigir os costumes e pensamentos. A política da arte, para ele, implica em um

\footnotetext{
1 "O livre jogo entre poiesis (a fala, a enunciação) e aisthesis (a consideração da fala) significa que a arte-estética não possui nenhum poder ordenador entre esses aspectos. Manter esse livre jogo é política porque desarticula a ordem policial. Nesta, as duas dimensões do logos - a fala e sua consideração - estão fixas, critalizadas e categorizadas" (MALIK; PHILLIPS, 2011, p.114)

2 "O regime estético das artes é primeiramente a ruina do sistema da representação que definia, por meio dos gêneros, as situações e as formas de expressão que convinham ao rebaixamento ou à elevação do sujeito. O regime estético das artes desfaz essa correlação entre sujeito e modo de representação."(RANCIÈRE, 2000a, p.48).
} 
distanciamento e uma suspensão de toda relação determinável entre a intenção de um artista e o olhar de um espectador.

Um outro problema recorrente da aproximação entre política e imagem consiste na percepção de que a imagem, para ser política, deve retratar as injustiças e mazelas sociais. Contrariamente a esse argumento, Rancière ressalta que não basta retratar uma situação social de penúria ou nutrir uma simpatia pelos explorados e desamparados para fazer uma imagem política. Também não basta evidenciar uma simpatia pelos subalternos e desamparados. Para ele, é equivocado pensar que a política da imagem derive de "um modo de representação que torne essa situação inteligível enquanto efeito de certas causas e que a leve a produzir formas de consciência e afetos que a modifiquem" (2009, p.53). A imagem não deve ser, segundo ele, reduzida a um texto que busque esclarecer as causas e efeitos das injustiças. Ela não pode se relacionar com o receptor em uma espécie de ligação contínua, que associa as intenções do produtor com as interpretações do receptor de maneira pacífica e imediata.

Um terceiro problema apontado por Rancière (2004b) na tentativa de construção de vínculos entre imagem e política está associado ao entendimento de que as formas artísticas deveriam ser orientadas pela preocupação de sairem de si para tornarem-se práticas de intervenção que transformem a realidade mesma das coisas. É como se a imagem (e a arte) tivesse (m) o papel de restaurar os elos entre os sujeitos e os mundos que habitam. Contudo, para Rancière "a arte não se dissolve em relações sociais. Ela constroi formas efetivas de comunidade: comunidades entre objetos e imagens, entre imagens e vozes, entre rostos e palavras que tecem os testemunhos entre os passados e um presente, entre espaços longíquos e um lugar de exposição" (2007, p.209).

O que é novo e significativo, portanto, não é a vontade de uma arte que saia de si mesma para agir diretamente no mundo. É a forma hoje assumida por essa vontade, uma forma de assitência individual aos mais desfavorecidos que tanto as vanguardas artísticas como os construtores do socialismo rejeitavam até pouco tempo atrás. O sonho de uma arte que construa as formas de uma 
vida nova tornou-se o projeto modesto de uma "arte relacional": arte que busca criar não mais obras, mas situações e relações, e nas quais o artista, como diz um teórico francês dessa arte, presta à sociedade "pequenos serviços" próprios a reparar "as falhas do vínculo social" (RANCIÈRE, 2004b, p.3).

Parto do pressuposto de que as imagens, segundo Rancière (2010a, 2012), não se configuram como políticas pelo teor da mensagem que carregam, nem muito menos por sua eficácia conscientizadora. Em vez disso, as imagens são políticas na medida em que podem devolver o dissenso e a ruptura a paisagens homogênenas, de concordância geral e assujeitamento:

\begin{abstract}
As práticas artísticas não são instrumentos que proporcionam formas de consciência nem energias mobilizadoras em benefício de uma política que seria exterior a elas. Tais práticas não saem de si mesmas para se converterem em formas de ação política coletiva. Elas contribuem para desenhar uma paisagem nova do dizível, do visível e do factível. Elas forjam contra o consenso outras formas de sentido comum, formas de um sentido comum polêmico.(RANCIÈRE, 2010a, p.77).
\end{abstract}

Somado a isso, uma imagem não pode ser considerada política por uma suposta capacidade que possui de reconstituir os vínculos sociais, possibilitando a "inclusão" de indivíduos subjugados, e, assim, uma erradicação de formas de opressão. "Trata-se de fazer com que a riqueza sensível e o poder da palavra e de visão que são subtraídos à vida e ao cenário das vidas precárias lhes possa ser restituído, possa ser posto à sua disposição" (RANCIÈRE, 2009, p.60).

A arte não deve visar a uma transformação do mundo, mas da relação entre os sujeitos que constroem e partilham um mundo. Qualquer poder de transformação supõe uma redistribuição imaginária dos lugares, uma mobilidade ininterrupta das situações subjetivantes (MONDZAIN, 2011, p.110).

Acerca do desejo dos artistas de promoverem rupturas na ordem consensual, cabe salientar a ressalva feita por Rancière aos artistas que 
expressam o desejo de subverter a ordem vigente. Para ele, não se deve questionar a ação de artistas e atores, a partir de suas ferramentas e lugares, para testemunhar uma realidade de desigualdades, de contradições e de conflitos que o discurso consensual tende a tornar invisíveis.

O problema é que esse esforço indiscutível de muitos artistas para romper o consenso dominante e questionar a ordem existente tende a se inscrever, ele próprio, no quadro das descrições e das categorias consensuais, reduzindo o poder artístico de provocação às tarefas éticas de testemunho sobre um mundo comum e de assistência aos mais desfavorecidos. (RANCIÈRE, 2004b, p.3).

Nesse sentido, Rancière defende, como mencionado acima, um regime estético para as artes, no qual "a arte estética muda o foco de uma análise da politica da arte para longe de suas demandas internas ou socialmente dirigidas em direção à sua capacidade estrutural de instanciar a política, efetuando uma relação diferente com o espectador." (MALIK; PHILLIPS, 2011, p.113). Sob esse aspecto, a arte estética se distingue das formas de arte que, por meio de seu conteúdo e de sua forma (lugar, uso de materiais, etc.) propõem uma agenda deliberativa social e ou política da noção histórica de arte crítica que Rancière caracteriza como produtora de uma atenção a mecanismos de dominação que transformam o espectador em um agente consciente da transformação do mundo.

Por meio do conceito de arte estética, Rancière aponta que a política não deve ser situada fora das imagens - nas pretensões dos artistas, nas adequações ou inadequações identificadas para a representação de lutas de grupos minoritários, nas repercussões e entelaçamentos de esferas públicas ou na construção de enquadramentos interpretativos críticos (ainda que essas dimensões sejam importantes). Se insistimos em atribuir politicidade à imagem tendo em conta um pretenso caráter de incidir de modo concreto e prático sobre injustiças, corremos o risco de adotar a postura de nos colocar diante das imagens julgando sua pertinência ou não a representações mais justas e plurais, apontando erros ou distorções passíveis de ocorrerem. Análises que consideram que a imagem é apenas um gatilho para que se encontre a política em outro lugar desconsideram 
elementos estéticos e discursivos próprios da imagem. Assim, não se pode tomar a política como ponto de partida das análises, interrogando os modos pelos quais as imagens, de maneira sintomática, dão a ver questões políticas presentes no mundo social. Afinal, como argumenta Rancière, "nós não estamos diante das imagens; estamos no meio delas, como elas estão no meio de nós. A questão é de saber como circulamos entre elas, como as fazemos circular"' (2007, p.198).

\section{Política da imagem}

A política da imagem associa-se, a meu ver, ao modo como a imagem pode desvelar potências, reconfigurar regimes de visibilidade e questionar ordens discursivas opressoras. A política da imagem é "a atividade que reconfigura os quadros sensíveis no seio do qual se dispõem os objetos comuns, rompendo com a evidência de uma "ordem natural" que define os modos de fazer, os modos de dizer e os modos de visibilidade" (HUSSAK, 2012, p.103). Sob esse aspecto, uma imagem é política quando deixam entrever as operações que influenciam na interpretação daquilo que vemos, ou seja, a potência política está tanto nas imagens (materialidade sígnica) quanto nas relações e operações que as definem.

Como afirma Rancière, “a imagem não é simplesmente o visível.É o dispositivo por meio do qual esse visível é capturado" (2007, p.199): "ela é uma ação que coloca em cena o visível, um nó entre o visível e o que ele diz, como também entre a palavra e o que ela deixa ver" (RANCIÈRE, 2008b, p.77).

A imagem jamais pode ser pensada de modo isolado, mas necessariamente dentro de uma imagerie, ou seja, um regime de relações entre elementos e funções das imagens. Essas operações consistem em estabelecer relações do todo com as partes, entre a visibilidade e o poder de significação, entre os afetos acoplados à imagem e os efeitos que eles criam, entre as expectativas e as realizações ou frustrações (HUSSAK, 2011, p.102). 
As imagens são, portanto, operações que produzem uma distância, uma dessemelhança: "relações entre um todo e as partes, entre uma visibilidade e uma potência de significação e de afeto que lhe é associada, entre as expectativas e aquilo que vem preenchê-las" (RANCIÈRE, 2012, p.11). Assim, as imagens nunca são simples realidade, mas antes um jogo de manifestação e ocultamento, um conjunto de relações e operações entre o dizível e o visível (HUSSAK, 2011). Essas operações influenciam na natureza política do que vemos, são as relações que definem as imagens, isto é as relações que se estabelecem dentro e fora do âmbito artístico, que pre-configuram enunciados, que montam e desmontam relações entre o vísivel e o invisível, o dizível e o silenciável, que deixam entrever a grande potência caóticadas desconexões, "própria para escapar ao torpor do grande consentimento".

Poderíamos ainda dizer que a política das imagens se revela a partir de uma interrupção, de uma "eficácia estética"3 por meio da qual se suspende toda relação entre narração e expressão, atraindo o espectador para um livre jogo entre estranhamento e significação. Aqui é preciso lembrar que, em Rancière, a estética é, de um lado, uma forma de refletir sobre a produção artística e, de outro, uma dimensão da política. Nesse segundo sentido, a estética está ligada à partilha do sensível, a modos de organização e divisão do tempo e do espaço e a como tais modos permitem coisas, objetos e pessoas se tornarem visíveis.

Podemos encontrar no pensamento de Rancière (2000a) duas formas da partilha do sensível, que são opostas em seus princípios e interligadas em seu funcionamento, às quais ele dá o nome de polícia e política. A partilha policial do sensível é a ordem que designa os modos de ser e dizer, quem faz isto ou aquilo, que define que esta palavra tenha importância e que a outra nem seja percebida. Ela configura uma ordem que determina um local específico para os sujeitos, limitando-os em seus nomes e funções por enquadrá-los em uma determinada visão fixa do

\footnotetext{
A eficácia estética significa a "eficácia de uma suspensão de toda relação direta entre a produção das formas de arte e a produção de um determinado efeito sobre um público específico. A arte tinha uma finalidade e seus efeitos eram antecipados. Significa a produção de efeitos por meio da suspensão dos fins representativos" (RANCIÈRE, 2010a, p.60).
} 
local de existência e importância deles. Por sua vez, a partilha política do sensível permite "dar a ver aquilo que não encontrava um lugar para ser visto e permitir escutar como discurso aquilo que só era percebido como ruído" (RANCIÈRE, 1995, p.53) ${ }^{4}$. A política ${ }^{5}$ é uma forma de questionar o consensual, o tido como dado, o inquestionável: ela irrompe diante de olhos acostumados à normalidade (e à normalização) e promove rupturas e transformações nos modos usuais de aparência e circulação de palavras, corpos e imagens.

Sob esse viés, imagens políticas são, portanto, imagens dissensuais, imagens que desconectam significações e visibilidades, que permitem o estranhamento e a polêmica. Trata-se de complexo exercício identificar a potência política e criativa que as imagens apresentam de se configurarem como dispositivo ou como operação que fazem surgir e sobreviver os "momentos inestimáveis" que resistem a capturas, silêncios e aos excessos de discursos construídos midiaticamente, pelas instituições sociais e pelo Estado.

Isso nos convida a investigar como as imagens produzem rearranjos das visibilidades e dos modos de dizer operantes no mundo. A potência política de uma imagem é aquela que produz, a partir de seus próprios meios expressivos, uma recombinação de signos capaz de desestabilizar as evidências dos registros discursivos dominantes. Dito de outro modo, é uma potência que se configura por meio do gesto de "jogar com a ambiguidade das semelhanças e a instabilidade das dessemelhanças, operar uma redisposição local, um rearranjo singular das imagens circulantes" (RANCIÈRE, 2012, p.34).

A redisposição, rearranjo ou mesmo reconfiguração das imagens circulantes são ações que podem ganhar corpo, segundo Rancière, por meio de uma partilha política do sensível pautada por uma distribuição

4 A partilha do sensível "consiste em disposições dos corpos, em recortes de espaços e de tempos singulares que definem maneiras de estar juntos ou separados, frente a ou em meio de, dentro ou fora, próximos ou distantes" (RANCIÈRE, 2010a, p.57).

5 "A política é a atividade que reconfigura os marcos sensíveis no seio dos quais se definem objetos comuns. Ela rompe a evidência sensível da ordem natural que destina aos indivíduos e grupos o comando da obediência, a vida pública e privada, assinalando-lhes desde o início tal ou qual tipo de espaço ou de tempo, tal maneira de ser, ver e dizer." (RANCIÈRE, 2010a, p.61). 
polêmica das maneiras de ser e das ocupações em um espaço de possíveis. A arte estética constrói "reagenceamentos/rearranjos materiais dos signos e das imagens, das relações entre o que vemos e o que dizemos, entre o que fazemos e o que podemos fazer" (RANCIÈRE, 2000a, p.62) e, com isso, pode "reconfigurar a carta do sensível ao dessarranjar a funcionalidade dos gestos e dos ritmos adaptados aos ciclos naturais da produção, da reprodução e da submissão.’(idem).

Mas esses reagenciamentos promovidos pela arte estética e pelas imagens se tornam possíveis a partir do momento que indagamos as imagens menos a partir de uma pretensa "mensagem política" a ser decifrada, e mais a partir dos dispositivos de visibilidade que definem e impõem constrangimentos e cerceamentos aos modos como se constróem, na imagem, possibilidades de apresentação e de aparência dos indivíduos determinadas por uma certa partilha consensual e policial do sensível.

Uma imagem nunca está sozinha. Pertence a um dispositivo de visibilidade que regula o estatuto dos corpos representados e o tipo de atenção que merecem. A questão é saber o tipo de atenção que este ou aquele dispositivo provoca (RANCIÈRE, 2012, p.96).

Ao apontar para regimes de visibilidade sob os quais as imagens são produzidas e através dos quais os sujeitos e corpos presentes na imagem têm seu modo de aparecer influenciado por constrangimentos próprios de um regime discursivo que as antecede, Rancière deixa claro que uma investigação acerca da política das imagens deve procurar observar o modo como os corpos representados "aparecem" e indicam possibilidades de resistência, subversões e reinvenções dos modelos de captura aos quais estão submetidos rotineiramente. Como destaca Agamben:

O que os seres humanos realmente são não é outra coisa senão essa dissimulação e essa inquietude com relação à aparência (aparecer). Porque os seres humanos não são e nem possuem nenhuma essência, natureza ou destino específico, sua condição é a mais vazia e insubstancial de todas. O que permanece 
escondido deles não é algo por trás da aparência, mas o próprio aparecer, ou seja, o ser nada além do rosto. A tarefa da política é trazer de volta à aparência a própria aparência, fazer com que ela apareça (2000, p.94-95).

Se a política das imagens está intrinsecamente ligada ao modo como, nas imagens, operações constituem regimes de visibilidade capazes tanto de regular e constranger o "aparecer” dos sujeitos, quanto de potencializálos, me parece instigante estudar tais operações a partir das noções de cena de dissenso e subjetivação política.

\section{Cenas de dissenso, rosto e subjetivação política}

Uma investigação sobre a política da imagem deve levar em conta o modo como a estética, entendida enquanto ação dissensual, desempenha operações de natureza política na imagem. Vimos anteriormente que o problema relativo a uma política (e uma ética) das imagens, para Rancière, se concentra no seguinte exercício (2010a, p.100): "saber como é posto e qual espécie de senso comumé tecido pela construção desta ou daquela imagem; saber que espécie de ser humano a imagem nos mostra e a que espécie de ser humano ela é destinada, que espécie de olhar e de consideração é criada por esta operação". Há aqui, dois movimentos implicados: olhar para os modos de "aparência" dos sujeitos na imagem e identificar que tipo de olhar e de implicações esse "aparecer" suscita junto àqueles que observam a imagem. E nessas duas operações, é a "aparência" que está em jogo:

Não há política senão na aparência, nela residindo a sua nobreza. A relação do ser com a aparência não deve ser compreendida como uma relação mimética, mas também não deve ser compreendida como uma oposição entre o escondido e o apresentado, entre o oculto e o manifesto: a política está sempre do lado do que se apresenta (TASSIN 2004, p.112). 
Os indivíduos, quando "aparecem", desencadeiam um processo de subjetivação que se estabelece em cenas polêmicas que são, por sua vez, também criadas pelo "aparecer". A caracterização da cena polêmica (ou cena de dissenso) é central no pensamento político de Rancière, uma vez que, para ele, o real objeto do conflito político é justamente a existência de uma situação de visibilidade e de fala, e o status de validade dos protagonistas e/ou participantes nessa situação. Cenas de dissenso se constituem, segundo Rancière, quando "ações de sujeitos que não eram, até então, contados como interlocutores, irrompem e provocam rupturas na unidade daquilo que é dado e na evidência do visível para desenhar uma nova topografia do possível" (2004a, p.55). São essas cenas polêmicas que permitiram a redisposição de objetos e de imagens que formam o mundo comum já dado, ou a criação de situações aptas a modificar nosso olhar e nossas atitudes com relação ao ambiente coletivo, questionando uma ordem dominante que apaga conflitos, diferenças e resistências. Em tais cenas, os sujeitos podem experimentar a política enquanto processo de criação de formas dissensuais de expressão e comunicação que inventam modos de ser, ver e dizer, configurando novos sujeitos e novas formas de enunciação coletiva. As cenas remetem à invenção de novas visualidades e interlocuções nas quais se inscrevem a palavra do sujeito falante, e nas quais esse próprio sujeito se constitui de maneira performática.

Rancière menciona Foucault ao sugerir que as cenas polêmicas, espaços que forçam a emergência de uma contradição entre a lógica consensual dos discursos estabelecidos e a ação política inventiva, não precisam e não deveriam descrever somente casos em que as partes em diálogo estejam já aparentemente presentes (em uma menção crítica à postura de Habermas). Às vezes a batalha discursiva da política democrática ocorre antes da "aparência" do sujeito em cena, ou seja, essas cenas polêmicas são produzidas em um nível mais amplo, no nível do discurso que deveria preceder a emergência do indivíduo como sujeito (CHAMBERS, 2005).

Na cena de dissenso questiona-se a injusta partilha do sensível promovida por um regime que Rancière nomeia de regime policial. Nesse 
regime, a partilha do sensível não é uma regra disciplinar ou máquina ideológica que fixa os indivíduos em seus lugares por um mecanismo de ilusão necessária ou contrôle do corpo. Mas são as relações entre o visível, o enunciável e o pensável que operam no espaço em que coisas são nomeadas, discursos são produzidos e ações são desempenhadas. A partilha do sensível efetuada pela ordem policial caracteriza um mundo no qual as imagens mediadas pelo contexto comunicacional buscariam um horizonte totalizante, um consenso ${ }^{6}$ que dilui a força criativa e a resistência do imaginário (MARQUES, 2013 a e b). Assim, o modo de partilha realizado pela ordem policial "não deixa alternativa, pois equaciona tudo ao simples constrangimento de uma ordem/estado de coisas" (RANCIÈRE, 2010a, p.185).

Já a partilha do sensível promovida pela política instaura uma cena de dissenso na qual se busca retirar os corpos de seus lugares assinalados, libertando-os de qualquer redução à sua funcionalidade. Para Rancière, essa cena mistura a dramaticidade da cena teatral com a racionalidade da cena argumentativa: "não se pode separar uma ordem racional de argumentação de uma ordem poética do comentário e da metáfora, pois a política é produzida por atos de linguagem que são, ao mesmo tempo, argumentações racionais e metáforas poéticas" (1995, p. 86). Em resposta a uma entrevista, Rancière comenta acerca da inventividade necessária para a criação da cena de dissenso:

A fim de entrar na troca política é preciso inventar a cena na qual palavras ditas se tornam audíveis, objetos se tornam visíveis e indivíduos podem ser reconhecidos. Essa atividade de invenção permite uma redescrição e reconfiguração do mundo comum da experiência. É nesse sentido que podemos falar da poética da política (PANAGIA, 2000, p.116).

A proposta de Rancière salienta, portanto, o caráter poético de constiuição das "cenas" criadas pelos sujeitos políticos quando desejam

6 O consenso estabelece um enquadramento conceitual e imagético para qualquer interação e discussão, cujas contradições passam despercebidas por coincidirem com interesses hegemônicos ou por refletirem situações existentes e vistas como inalteráveis. Por isso, ele reduz os sujeitos a parceiros de interlocução com interesses a serem defendidos e transforma o processo político em jogo de especialistas (RANCIÈRE, 2004a). 
colocar à prova o estatuto igualitário que lhes é garantido pelas leis e normas (MARQUES, 2013a). A poética da política, ou a existência de uma base estética para a política, além de ser um desafio à oposição entre interlocutores legítimos e ilegítimos, remete à invenção da cena de visibilidade/aparência e de interlocução na qual se inscreve o rosto e a palavra do sujeito, e na qual esse próprio sujeito se constitui de maneira performática.

Na cena polêmica, os indivíduos aparecem e, nessa ação, "manifestam-se e desejam tomar posse dessa abertura para o mundo e para o outro. Essa apropriação da aparência, feita pela linguagem, transforma natureza em rosto" (AGAMBEN, 2000, p.91). Nesse movimento de exposição, os indivíduos se transformam em sujeitos dotados de rosto, capazes de desenvolver capacidades enunciativas e demonstrativas de reconfigurar a relação entre o visível e o dizível, entre palavras e corpos. Cabe salientar que o rosto não se confunde com a face, mas é uma metáfora para dizer da constituição do sujeito político, daquele que aparece no espaço coletivo de exposição, argumentação e negociação. Esse me parece um conceito pertinente para estudar "modos de subjetivação emergentes, focos de enunciação coletiva, territórios existenciais, inteligências grupais que escapam aos parâmetros consensuais, às capturas do capital"' (PELBART, 2003, p.22).

A imagem pode conferir rosto a um indivíduo, tornando-o sujeito a nossos olhos, e, por isso, por permitir sua aparência, faz emergir o lugar da política. É nesse sentido que a a fotografia pode se configrurar como esse lugar de exposição e emergência do rosto e, ao mesmo tempo, de criação de uma cena na qual se dá a subjetivação. Cada rosto fotografado possui a sua identidade própria, singular, individual, que não pode ser generalizada e apagada, como bem quer a ordem policial que limitaria e definiria o significado dos signos que podem ser dele depreendidos.

A fotografia tornou-se uma arte, fazendo falar duas vezes o rosto dos anônimos: como testemunhas mudas de uma condição inscrita diretamente em seus traços, suas roupas, seu modo de vida; e 
como detentores de um segredo que nunca iremos saber, um segredo roubado pela imagem mesma que nos traz esses rostos (RANCIÈRE, 2012, p.23).

Rostos que emergem na superfície fotográfica, deixando de ser apenas faces ${ }^{7}$, expressam uma singularidade incomensurável e, de outro, uma operação que torna comum. Segundo Agamben, "compreender a verdade do rosto significa tomar não a semelhança, mas a simultaneidade dos semblantes, a inquieta potência que os mantêm juntos e os reúne em comum" (2000, p.99). O rosto aciona a política, tal como conceituada por Rancière, porque permite uma prática específica de configuração de um mundo comum, um mundo polêmico, de dar forma à identidade e à alteridade.

Em sua própria imediaticidade, o rosto é sempre duplo: o olhar reflete uma visão, as rugosidades dos lábios retêm um pensamento. É a partir desse núcleo de alteridade primeira que a circulação das imagens faz comunidade por círculos ampliados (RANCIÈRE, 2007, p.201).

O rosto está sempre entre a singularidade e a comunidade (Picado, 2009). Por isso, imagens que focalizam o rosto podem ser pensadas como o lugar do outro que se transforma na promessa do meu próprio lugar, assumindo caráter estético, ético e político, num processo intermitente de produção de gestos subjetivantes.

[...] a imagem vem ocupar um lugar entre os sujeitos do olhar, ocupar o sítio da mediação entre instâncias que estruturalmente não têm nenhuma relação; mas, por outro, também é preciso entender que se a imagem produz uma ligação entre sujeitos separados, entre sujeitos da desligação, ela assegura a distância que os separa, preservando-os de qualquer fusão identificadora ou massificante (MONDZAIN, 2011, p.124).

7 "O rosto não coincide com a face. Há um rosto sempre que alguém ou algo busca o nível de exposição e tenta se apropriar de seu próprio ato de ser exposto, sempre que um ser que aparece mergulha nessa aparência e tenta achar uma saída para dela escapar" (AGAMBEN, 2000, p.92). 
Daniel Bougnoux, assim como Agamben, também salientam esse caráter que o rosto possui de abertura à alteridade, ou de passagem e encontro entre o eu e o outro. $\mathrm{O}$ rosto que dá acesso ao mundo do outro nãoé passível de ser escrutinizado e resiste infinitamente a nossos esforços de aproximação e apropriação. Para ele, o rosto, entendido como objeto e sujeito do olhar, o rosto tece uma intriga relacional (capaz até de ser observada em paisagens e objetos).

O rosto que dá acesso ao mundo do outro não é passível de ser escrutinizado e resiste infinitamente a nossos esforços de aproximação e apropriação. Diante do rosto, só podemos responder e entrar na intriga, sem um programa traçado anteriormente nem uma transparência anterior. $\mathrm{O}$ rosto nos remete à relação e a copilotagem incerta de tal relação lembra a cada um a incompletude constitutiva de seu saber e de seu desejo. A atração inspirada por um rosto é impossível de ser circunscrita e satisfeita. Matéria relacional, o rosto se abre e se embeleza quando é animado pelo olhar do outro, ou no calor de uma conversação. O rosto não se contenta em ser visto, ele se ilumina e às vezes se transfigura na intensidade de certas trocas (BOUGNOUX, 2002, p.11).

O rosto se construiria, então, entre um fundo comum (comunidade) e a face singular (DREVET, 2002, p.23). Essa singularidade, segundo Debray (1999), está relacionada ao intenso trabalho do tempo sobre o rosto, e ao enigma que lança àquele que o observa. Para Agamben (2000), o modo de interação pragmática instaurado pelo rosto apresenta-se, ao mesmo tempo, como uma abertura à comunicabilidade e uma forma de expressão da comunidade:

A revelação do rosto é a revelação da própria linguagem. Essa não tem, conseqüentemente, nenhum conteúdo real, não diz a verdade sobre esse ou aquele estado da alma ou de fato, sobre esse ou aquele aspecto do homem ou do mundo: é unicamente abertura, unicamente comunicabilidade. Caminhar pela luz do rosto significa ser essa abertura, padecer dela. (AGAMBEN, 2000, p.75).

Retomando a questão da singularidade e estereotipagem dos rostos que emergem na fotografia, considero interessante refletir acerca dos 
apontamentos que Didi-Huberman (2011, p.67) tece acerca dos povos sem rosto, isto é, "a classe oprimida, exposta a desaparecer ou a ser subexposta nas representações consensuais da história". Para esse autor, os povos ou estão subexpostos na sombra da censura a que são sujeitos ou sobreexpostos na luz de sua espetacularização. Em ambos os casos, estariam fadados a desaparecer:

A subexposição priva-nos dos meios para ver, pura e simplesmente, aquilo que poderia estar em causa. (...) Mas a sobreexposição vale pouco mais: demasiada luz cega. Os povos expostos à ruminação estereotipada de imagens são, também eles, povos expostos a desaparecer. (...) Se os povos estão expostos a desaparecer, devese isso também ao fato de se terem formado discursos para que, já não vendo nada, possamos ainda crer que tudo se mantém acessível, que tudo permanece visível e, como se costuma dizer, sob controle. (DIDI-HUBERMAN, 2011, p.41 e 45).

Acredito que os povos sem rostos, fadados à desaparição pela invisibilidade construída pelo discurso predominantemente consensual dos holofotes midiáticos resistem ainda, porque não se deixam reduzir a conteúdos discursivos dados à interpretação conduzida. Se há formas de vida na imagem, são elas que impedem os rostos de desaparecerem sob a luz do discurso consensual.

O rosto não pode ser correlacionado a um saber que procura uma forma de adequá-lo, decifrá-lo. Assim, olhar para o rosto que se expõe na fotografia implica menos explorar suas formas de desaparição e mais buscar seus indícios de resistência, de subjetivação, de revelações que possam evidenciar como os fotografados encontram formas de criar hiatos, dissonâncias e dissensos entre seu "aparecer" e o registro (visual e verbal) de sua exposição.

O rosto é significação sem contexto. Outrem, na retidão de seu rosto, não é uma personagem num contexto. Normalmente somos personagens: é-se professor na Sorbonne, vice-presidente do Conselho de Estado, filho de fulano, tudo o que está no passaporte, a maneira de se vestir, de se apresentar. E toda a 
significação, no sentido habitual do termo, é relativa a um contexto: o sentido de alguma coisa está na sua relação com outra coisa. Aqui, pelo contrário, o rosto é sentido só para ele. Tu és tu. Nesse sentido, pode dizer-se que o rosto não é visto. Ele é o que não se pode transformar num conteúdo, que o nosso pensamento abarcaria; é o incontível, leva-nos além (LEVINAS, 2007, p.70).

A emergência do rosto marca, portanto, o início de um processo de subjetivação política. A subjetivação, em Foucault (1995) e em Rancière (2004a), nomeia tanto o processo de se tornar sujeito quanto o processo político de nomear constrangimentos de poder e injustiças: ela torna visível o hiato entre a identidade de alguém dentro da ordem consensual dada (na distribuição de papéis, lugares e status) e uma certa demanda se subjetividade por meio da ação da política ${ }^{8}$. Sob esse aspecto, Rancière ressalta que, por subjetivação entende-se "a produção, por uma série de atos, de uma instância e de uma capacidade de enunciação que não eram identificáveis em um campo de experiência dado, cuja identificação está ligada à reconfiguração do campo da experiência" (1995, p.59). Se o processo de subjetivação política redefine o campo da experiência que outorgava ao indivíduos uma identidade pré-definida, devemos nos indagar acerca de como se dá essa redefinição.

De acordo com Rancière (2010b), se há algo de próprio na política, ele consiste na relação, que não é uma relação entre sujeitos, mas entre dois termos contraditórios que definem um sujeito (um nome que o reduz ao lugar destinado pela ordem policial e outro nome que o permite vivenciar as cenas de dissenso e a apropriação criativa de si). Segundo ele, a subjetivação produz cenas polêmicas nas quais não mais há uma correpondência exata entre nomes e indivíduos. ${ }^{9}$ Se a ordem discursiva

\footnotetext{
8 Apesar das perspectivas de Foucault e Rancière se aproximarem em vários pontos, é preciso lembrar que enquanto Rancière afirma que a ética neutraliza a política e a emergência do sujeito político, Foucault constrói uma abordagem ética da subjetivação, apostando em uma apropriação criativa de si, na qual os sujeitos são capazes de dirigir suas condutas e posicionamentos sociais.

9 "A lógica da subjetivação política não é jamais a simples afirmação de uma identidade, ela é sempre, ao mesmo tempo, a negação de uma identidade imposta por um outro, fixada pela lógica policial. A polícia deseja nomes exatos, que marquem para as pessoas o lugar que ocupam e o trabalho que devem desempenhar, A política, por sua vez, diz de nomes «impróprios » que apontam uma falha e manifestam um dano." (RANCIÈRE, 2004a, p.121)
} 
prevalecente oferece apenas um nome para um indivíduo, assujeitando-o e dificultando a emergência de sua pluralidade e de sua capacidade de ação, a criação de cenas polêmicas visa permitir a emergência do sujeito via linguagem. Dito de outro modo, a subjetivação política diz respeito a desidentificações: a rupturas com uma ordem discursiva que oferece a cada pessoa seu lugar na ordem das coisas, um lugar atrelado à uma identidade. A subjetivação política não é o "reconhecimento de" ou o gesto de "assumir uma identidade", mas o desligamento com essa identidade, a produção de um hiato entre a identidade da ordem vigente e uma nova subjetividade política (MARQUES, 2011). Trata-se de um cruzamento de posições de sujeito que repousa sobre um cruzamento de nomes: aqueles impostos e aqueles criados pelas próprias mulheres. Sendo assim, a lógica da subjetivação política não é jamais a simples afirmação ou negação de uma identidade, ela é sempre, ao mesmo tempo, a conexão e desconexão entre um lugar de fala percebido como próprio e uma identidade imposta por um outro, fixada pela lógica policial (Rancière, 2004a).

A subjetivação não identitária em Rancière, ou desidentificatória, concerne, além disso, a uma figura política coletiva, não individualizada (o demos, os sem-parte ${ }^{10}$, os pobres, assim como a figura dos povos criada por Didi-Huberman), problematizando o processo de universalização de atores particulares, em situações de luta particulares, sob a forma da constituição de um sujeito plural, coletivo, não redutível à demanda de uma comunidade de sujeitos preidentificados (através das categorias de classe, raça, sexo, ou pelas categorias socioprofissionais). É um tipo de subjetivação que envolve o jogo de enunciação e a forma como os indivíduos aparecem na cena pública dissensual (TASSIN, 2012).

Esse é o trabalho da subjetivação política que inventa sujeitos que tomam consciência de si e de sua multiplicidade no entrecruzamento de

10 “As pessoas que compõem o sujeito da democracia (...) são menos grupos sociais (ligados a raça, pobreza, trabalho - não são os negros, pobres ou trabalhadores) e mais formas de inscrição que dão a perceber uma conta dos que não são contados ou da parte dos sem-parte. (...)o sujeito político não é um grupo de interesses ou ideias, mas o operador de um dispositivo particular de subjetivação de litígio por meio do qual a política passa a existir."(RANCIĖRE, 2010 b, p.33, 35 e 39) 
vários nomes e lugares de pertencimento. Ela tenta fazer com que o sujeito se desprenda de limitações impostas, expressas pelo lugar, papel e nome que recebem na ordem policial, para dizer de seu mundo através do olhar e da alteridade convocadora do rosto.

\section{Considerações finais}

Como mencionado, a política das imagens não se encontra no gesto de fazer denúncias, de solicitar do espectador solidariedade ou identificação com as personagens retratadas. Em vez disso, ela estaria na possibilidade de desconstruir imagens pejorativas, recriando, pelo discurso e pela interação inusitada, vozes e rostos, devolvendo-lhes nuances e facetas até então desconsideradas, possibilitando com isso, um processo de desidentificação. Tal processo abrange um questionamento da naturalidade com que aos sujeitos é atribuído um lugar à abertura de um espaço de sujeito no qual se inscrevem em cenas enunciativas por meio do discurso, da argumentação e dos recursos poéticos da experiência.

A política das imagens se deixa entrever porque a imagem não é uma coisa, um objeto, um discurso, o visível: ela é, como salientou Rancière, um conjunto de operações que permite a existência do vísível. Nesse sentido, "quando a imagem não é uma coisa, ela provoca o advento de alguém" (MONDZAIN, 2011, p.106). Ela opera relações e regula as distâncias entre as pessoas que compõem o "povo"conferindo-lhes novas possibilidades de "aparecimento" público. Operações de visibilidade conjugam palavras e imagens de modo a fazer aparecer alguém em uma cena polêmica, na qual o processo de subjetivação política dá a ver um povo, um demos, uma parte dos sem-parte. Acredito que os processos de subjetivação ligados à aparência/exposição e apropriação criativa do corpo estão ligados tanto à tensão que se estabelece entre política e polícia, quanto à ação do próprio sujeito de expor-se e explicar-se, geralmente por meio da "exposição" e das "práticas de si”. 
A potência que as imagens possuem de encarnar, de tornar visível uma ausência, de produzir visibilidades sem substância ou verdade é o que torna, para Mondzain (2009), uma imagem política. Segundo ela, na imagem encarnada constituem-se três instâncias indissociáveis: o visível, o invisível e o olhar que os coloca em relação. A imagem "está entre os sujeitos e o sentido da imagem está entre as imagens" (MONDZAIN, 2011, p.109). Eé justamente porque ela opera entre sujeitos, constituindo potências de aproximação, separação, convocação e desinteresse, que sua dimensão política e ética pode ser avaliada. Ao regularem as distâncias entre as pessoas (ou povos) que compõem uma dada sociedade, as imagens não são o lugar da reconciliação e da identificação. Elas não são operadores do mesmo, mas o agente da heterogênese, do dissenso e da política.

\section{Referências}

AGAMBEN, Giorgio. O rosto. In: Means without end: notes on politics. University of Minnesota Press: Minneapolis, 2000, p.91-100.

. O que é o contemporâneo ? e outros ensaios. Chapecó : Argos, 2009.

BOUGNOUX, Daniel. Faire visage, comme on dit faire surface, Les Cahiers de Médiologie, n.15, "Faire Face", 2002, p.9-15.

CHAMBERS, Samuel. The politics of literarity. Theory and Event, 2005 , v.8, n.3.

. The Lessons of Rancière. Oxford: Oxford University Press,

2013. 
DEBRAY, Regis. "Les matières de l'âme: le visage entre pierre et cyber”. In: Croire, voir, faire: traverses, Paris: Jacob (Odile), 1999, p.225-240.

DREVET, Patrick. « Le désir de visage ». In : Les Cahiers de Médiologie, n.15, "Faire Face", 2002, p.17-23.

DIDI-HUBERMAN, Georges. Coisa pública, coisa dos povos, coisa plural. in A República por Vir: Arte, Política e Pensamento para o Século XXI, ed. Leonor Nazaré e Rodrigo Silva. Lisbonne: Fondation Calouste-Gulbenkian, 2011, p.41-70.

. La emoción no dice "yo": diez fragmentos sobre la libertad estética. In: AAVV, Alfredo Jaar. La política de las imágenes, Santiago de Chile, editorial Metales pesados, 2008, p.39-67.

FOUCAULT, Michel.'O sujeito e o poder". In: RABINOW, P.; DREYFUS, H. (eds.). M. Foucault: uma trajetória filosófica para além do estruturalismo e da hermenêutica. Rio de Janeiro: Rorense Universitária, 1995.

. Les techniques de soi. In: DEFERT, Daniel; EWALD,

François; LAGRANGE, Jacques. Dits et écrits. 1954-1988. Paris: Gallimard, 1984.

HUSSAK, Pedro. Rancière: a política das imagens. Princípios, v.19, n.32, 2012, p.95-107.

. Produção estética, emancipação e imagem em Jacques Rancière. In: Luciano Vinhosa Simão. (Org.). Horizontes da arte: práticas artísticas em devir. 1ed.Rio de Janeiro: NAU, 2011, v. , p. 92-104. 
LEVINAS, Emmanuel. Ética e infinito. Lisboa: Edições 70, 2007, p.69-75.

MALIK, Suhail; PHILLIPS, Andrea. The wrong of contemporary art: aesthetics and political indeterminacy. In: BOWMAN, Paul; STAMP, Richard. Reading Rancière. London: Continuum International Publishing Group, 2011, p.111-128.

MARQUES, A. C. S. Comunicação, estética e política: a partilha do sensível promovida pelo dissenso, pela resistência e pela comunidade. Galáxia (São Paulo. Online), v. 11(22), p. 25-39, 2011.

- Três bases estéticas e comunicacionais da política: cenas de dissenso, criação do comum e modos de resistência. Revista Contracampo, v. 26, n. 1, 2013a, pp.126-145.

. Cenas de dissenso e a política das rupturas e fraturas na evidência do visível In: Visualidades hoje.1 ed.Salvador : EDUFBA, 2013b, v.1, p. 243-262.

MONDZAIN, Marie-Jos. "Nada, tudo, qualquer coisa. Ou a arte das imagens como poder de transformação", in A República por Vir: Arte, Política e Pensamento para o Século XXI, ed. Leonor Nazar e Rodrigo Silva. Lisbonne: Fondation Calouste-Gulbenkian, 2011, p.103-128.

. A imagem pode matar? Lisboa: Nova Vega, 2009.

PANAGIA, Davide. Dissenting words: a conversation with Jacques Rancière. Diacritics, v.30, n.2, 2000, p.113-126.

PELBART, Pete Pál. Vida capital: ensaios de biopolítica. São Paulo: Iluminuras, 2003. 
. Subjetivação e dessubjetivação. In: O avesso do niilismo: cartografias do esgotamento. São Paulo: n-1 edições, 2013, p.225-236.

PICADO, Benjamim. AAção e a Paixão que se Colhem num Rosto: pensando os regimes de discurso do retrato humano no fotojornalismo. Galáxia (PUCSP), v. 18, p. 284-299, 2009.

. Das Feições do Cargo ao Face-a-Face pela Imagem: poética do retrato fotográfico na política. E-Compós (Brasília), v. 12, p. 1-18, 2009.

RANCIÈRE, Jacques. La Mésentente- politique et philosophie. Paris: Galilée, 1995.

. Políticas da Escrita. Rio de Janeiro: Ed. 34, 1996.

. Le Partage du Sensible: esthétique et politique. Paris: La Fabrique éditions, 2000a.

. Literature, Politics, Aesthetics: Approaches to Democratic

Disagreement. Interviewed by Solange Guénoun and James H. Kavanagh, Substance, n.92, 2000b, p.3-24

Aux bords du politique. Paris: Gallimard, 2004a.

. A arte além da arte. Folha de S. Paulo, Mais, 24/10/2004b, p.3.

. Le travail de l'image. Multitudes, n.28, 2007, p.195-210.

. As Desventuras do Pensamento Crítico. In: Crítica do contemporâneo: Giorgio Agamben, Giacomo Marramao, Jacques Rancière, Peter Sloterdijk. São Paulo: Fundação Serralves, 2008a, p.79-102. 
. El teatro de imágenes. In: AAVV, Alfredo Jaar. La política de las imágenes, Santiago de Chile, editorial Metales pesados, 2008b, p.69-89.

. Política de Pedro Costa. In: Cem Mil Cigarros - os filmes de Pedro Costa. Ed. Ricardo Matos Cabo, Lisboa: Orfeu Negro, 2009, p.53-63.

. O espectador emancipado. São Paulo: Martins Fontes, 2010a.

. Ten Thesis on politics. In : Dissensus: on politics and aesthetics. Edited and transleted by Steven Corcoran. London : Continuum, 2010b, p.27-43.

. The thinking of dissensus: politics and aesthetics. In:

BOWMAN, Paul; STAMP, Richard. Reading Rancière. London: Continuum International Publishing Group, 2011, p.1-17.

. O destino das imagens. Rio de Janeiro: Contraponto, 2012.

PELBART, Pete Pál. Vida capital: ensaios de biopolítica. São Paulo: Iluminuras, 2003.

TASSIN, Étienne. La question de l'apparence. Politique ET Pensée: Colloque Hannah Arendt, Paris: Payot, 2004.

. De la subjetivación política. Althusser, Rancière, Foucault, Arendt, Deleuze. Revista de Estudios Sociales, n.43, 2012, p.3649. 